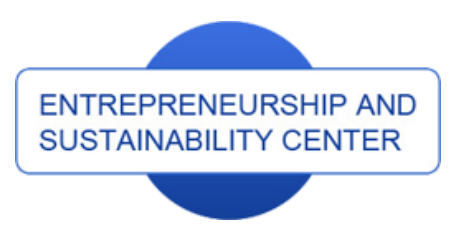

Publisher

http://jssidoi.org/esc/home enterprise

europe

network

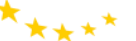

Business Support on Your Doorstep

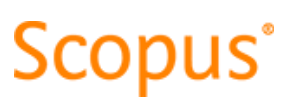

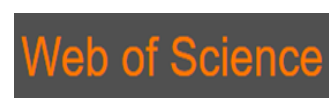

Clarivate
Analytics

\title{
INTELLECTUAL INPUT OF DEVELOPMENT BY KNOWLEDGE-BASED ECONOMY: PROBLEMS OF MEASURING IN COUNTRIES WITH DEVELOPING MARKETS
}

\author{
Rimma Sagiyeva', Aziza Zhuparova ${ }^{2}$, Rashid Ruzanov $^{3}$, Raigul Doszhan ${ }^{4}$, Askar Askerov $^{5}$ \\ 1,2,4,5 al-Farabi Kazakh National University, Almaty, Kazakhstan \\ ${ }^{3}$ Institute of Economics, Almaty, Kazakhstan \\ E-mails:²aziza_z@mail.ru
}

Received 16 July 2018; accepted 25 October 2018; published 30 December 2018

\begin{abstract}
Over the past 20 years, sales volumes in the knowledge-intensive sectors of the developed world grew about 2 times faster than in the manufacturing industry. It is no coincidence that the share of knowledge-intensive sectors of the manufacturing industry and the service sector today accounts for an average of more than half the GDP of the leading industrial countries. A new, knowledge-based economy creates new resources that effectively replace natural resources and human intellect. A high-end economy is the creation of new, artificial energy and artificial intelligence and their use in all sectors of the economy. In addition, a knowledge-intensive economy is a large-scale use of scientific developments, a new content of labor and the attitude of all its participants to it. A high-tech economy is born and is able to develop in a social environment with a sufficient level of intellectual development of society. The creation of such an economy requires not only a high level of development and implementation of new resource-creating and resource-saving technologies, but also a mass knowledge of new technologies, skills to use in production and everyday life. A high-tech economy is formed in conditions of sufficient intellectual security. With all this, the urgency of finding answers to the questions is growing: what conditions are necessary for the creation and functioning of a knowledge-based economy. In this regard, firstly, the article compares the level of development of human resources in the Republic of Kazakhstan with other countries of the world, which allows us to conclude that in terms of quantitative indicators (coverage of primary, secondary, vocational and higher education, life expectancy), our country has average positions in the world ranking. Secondly, in order to identify the relationship between a number of indicators of the method of assessing intellectual security in Kazakhstan, a correlation analysis for 2004-2017 was conducted. This article expands the knowledge on methods of assessing intellectual security for the development of a knowledge-based economy in developing countries.
\end{abstract}

Keywords: knowledge-based economy, intellectual potential, evaluation of intellectual potential, intellectual provision

Reference to this paper should be made as follows: Sagiyeva, R,; Zhuparova, A.; Ruzanov, R.; Doszhan, R.; Askerov, A. 2018. Intellectual input of development by knowledge-based economy: problems of measuring in countries with developing markets, Entrepreneurship and Sustainability Issues 6(2): 711-728. http://doi.org/10.9770/jesi.2018.6.2(17)

JEL Classifications: J24, O15 


\section{Introduction}

Humanity entered the 21st century, reconstructing all spheres of life under the influence of the requirements of the new technological order - Industry 4.0. The use of high-tech industries and artificial intelligence allows not only qualitatively changing the economic system, but also creating new resources that replace natural, changing the way of life of society and the competitiveness of states.

As is known, civilizational technological transformation historically and logically occurred under the influence of new knowledge used in the economy. At the same time, on the whole, the technological progress and personal development of Man took place in a dialectical unity, forming the corresponding model of the economy: from the traditional (based on primitive means of production and manual labor) to the modern - science intensive. In turn, the changing modes of production and social development respectively developed the person: his knowledge, way of thinking, type and character of behavior.

A characteristic feature of the modern knowledge-based economy is not only the creation and use in all spheres of society of new resources with specified properties and effectively replacing natural resources, but also the replacement of certain functions of the human brain with artificial intelligence. In addition, a knowledge-intensive economy is an expanded reproduction of scientific developments, a new content of labor and the attitude of all its participants to it. A high-tech economy is born and is able to develop in a social environment with a sufficient level of intellectual development of society, since it requires a mass knowledge of new technologies, the ability to use them in production and everyday life. Thus, a knowledge-based economy is formed in conditions of sufficient intellectual security. In this regard, the urgency of finding answers to the questions is growing: "What and in what quantity are intellectual resources needed for the creation and functioning of a knowledge-based economy in Kazakhstan that is striving to move away from the catch-up development model?", "What methods of measuring intellectual potential and intellectual capital can be used for national the economy of Kazakhstan in the context of the transition to a knowledge-based economy?".

\section{Literature review}

Intellectual potential and the effectiveness of its use - are the main drivers of economic development of a new type. The development of methodological approaches for determining the quantitative and qualitative parameters of the intellectual provision of a knowledge-based economy presupposes the specification of the principles and criteria for selecting indicators that characterize the degree of development of intellectual potential and intellectual capital necessary and sufficient for a knowledge-based economy.

In the literature, there are many methodological approaches to identifying quantitative and qualitative characteristics of intellectual capital, capable of ensuring the progressive development of a knowledge-based economy. The authors specify and supplement them depending on the level of the economic hierarchy (macro-, meso-, and microlevels), the level of development of national economies, the favorable socio-economic context, the agglomeration of economic activity, the availability of technological infrastructure, etc.

The toolkit for measuring intellectual potential and intellectual capital is so diverse that obviously it makes sense to focus only on the most famous.

Before, to determine how it is necessary to evaluate intellectual security, let's define the concept of intellectual potential. So according to the definition (Bontis, 2004) intellectual potential is defined as the ability of people to engage in and carry out activities that are important for regional economic and social development. It represents the intellectual wealth of all people from a certain region. The intellectual potential of the region is determined not 
by the educational achievement of its inhabitants, but by the extent to which it is able to preserve and develop this human potential and use it for economic growth.

Ilyashenko S.N. (2004) notes that intellectual potential is singled out as a separate component in the structure of innovation potential along with personnel, market, technological, information, interface, and research. In his opinion, intellectual potential should determine the possibilities of generation and perception of ideas and ideas of innovations and bringing them to the level of new technologies, designs, organizational and managerial decisions. Balatsky OF (2004), in turn, notes that the main carriers of innovation potential are information resources in the form of scientific and technical information, in the form of the results of fundamental research, scientific discoveries, inventions, scientific and developmental developments. Here the innovative potential is called upon to create conditions for the most complete development of labor, production, investment, natural resource and institutional capacities.

To the very first works on the evaluation of intellectual potential can be attributed the works of the scientist P. Dryuker (1992). His evaluation methodology included three indicators:

- Evaluation of the institutional regime that facilitates efficient mobilization and allocation of resources, stimulation of creativity and motivation for the creation, dissemination and use of new knowledge;

- the availability of educated and skilled workers who can continuously improve and adapt their skills for the effective creation and use of new knowledge;

- the effectiveness of the innovation system of firms, research centers, universities.

Since the company's intrinsic value as such does not create value or does not generate growth, but can be developed and brings success only in a specific context or through optimal management, Lev and Daum (2004) supplemented the methodology by assessing the effectiveness of managing intellectual capital.

Skirme (Skyrme, 2007) believes that the evaluation of intellectual potential should be carried out using the number of publications. In his opinion, it is the commercialization of innovations that makes it possible to distinguish innovative companies. Bek (Bec, 2014) also believes that the evaluation of results in the form of publications and patents is very important, in addition he suggested including in the evaluation the effectiveness of financing R \& D.

Lin Yeh-yun and Edvinsson (Lin Yeh-Yun and Edvinsson 2010) proposed a more thorough method for evaluating the intellectual potential. In his opinion, the intellectual potential of the region consists of five components: human capital, market capital, organizational and technological capital, material capital and financial capital.

International organizations involved in researching the problems of the development of innovative activities also attach considerable importance to methods for assessing intellectual potential. The most known techniques are discussed in Table 1.

Table 1. Review of methodologies for evaluating the intellectual potential of international organizations

\begin{tabular}{|l|l|}
\hline $\begin{array}{l}\text { The name of the } \\
\text { organization }\end{array}$ & \begin{tabular}{l} 
The content of the methodology and the criteria used \\
\hline UNDP, (1998)
\end{tabular} \\
$\begin{array}{l}\text { - - the development of the information society is led by rapid innovations in science, communications and } \\
\text { computing technologies; } \\
- \text { - technological progress in the field of information and communication technologies (ICT) - the number of } \\
\text { Internet users; } \\
- \text { - the ability to accumulate human intelligence and information technology. }\end{array}$ \\
$\begin{array}{l}\text { (1999) World Bank } \\
\text { countries; }\end{array}$ \\
$\begin{array}{l}\text { - - Investments and the country's achievements in the field of external relations, combined with the export of } \\
\text { quality products and services constitute a significant component in the development of market capital, which is rich } \\
\text { in intangible assets; } \\
- \text { - social intelligence, created by elements such as laws, market institutions and social networks. }\end{array}$ \\
\hline
\end{tabular}




\begin{tabular}{|l|l|}
\hline IFAC (1998) & $\begin{array}{l}\text { - - the effectiveness of the legal environment; } \\
\text { - - number of patents, licenses, copyrights and others; } \\
\text { - - the spread of the Internet and information technology; } \\
- \text { - the influence of intellectual capital. }\end{array}$ \\
\hline $\begin{array}{l}\text { European } \\
\text { Commission (2013) }\end{array}$ & $\begin{array}{l}\text { - - number of patents, publications; } \\
\text { - - the existence of community projects and licensing and patent revenues from abroad; } \\
\text { - - expenditure on innovation, not related to R \& D. }\end{array}$ \\
\hline OECD (1999) & $\begin{array}{l}\text { - availability of skilled labor; } \\
\text { - degree of education of employees; } \\
\text { - the degree of literacy; }\end{array}$ \\
\hline $\begin{array}{l}\text { Romilio Labra, M., degree of admission to higher education institutions; } \\
\text { \& Paloma Sánchez, } \\
2013\end{array}$ & $\begin{array}{l}\text { - an estimation of the intellectual capital of the nation, which includes } 4 \text { components of the evaluation of human } \\
\text { capital, technological capital, renewable capital and market capital. }\end{array}$ \\
\hline
\end{tabular}

Thus, a review of the existing methodological approaches to assessing intellectual potential and intellectual capital allows us to conclude that the variety of existing methods for measuring them is determined by three main factors:

- the complexity of measuring the creative abilities of a person;

- the difficulty in measuring the contribution of new knowledge to the economy;

- specifics of the national socio-economic context;

- the degree of use of modern information technology.

It should be recognized that the quantitative parameters of intellectual support for the development of a knowledge-based economy do not always coincide with qualitative parameters. It is no secret that the presence of a certain number of scientific personnel or innovative projects that they implement, does not always bring the result, from the point of view of increasing the science intensity of production, necessary. In our opinion, the quality of intellectual support can be checked by the effectiveness of using intellectual capital. This is a real generation of new useful ideas, the number of which does not always depend on the number of workers employed in the scientific sector.

\section{The place of Kazakhstan in the world supply with the intellectual resources of a knowledge-based economy}

Experience shows that many developed countries of the world, without their own raw materials, nevertheless successfully develop their economies and ensure a high standard of living for the population. A typical example here is Japan. In Japan, the technological orientation of the economy dominates and the intellectual resources of the nation are effectively used, which, in addition, compensates for the lack of own raw materials. A similar situation is observed today in South Korea, Taiwan, Singapore and in many other countries of the world, which relied on the strategy of technological development.

Let us examine in more detail the dependence of the country's economic development on the provision of intellectual resources.

To analyze the dependence of the level of economic development of some countries of the world on the level of qualification of their workforce, let us consider in the table below the data on the distribution of the world's skilled labor (CBC) resources between some countries (Table 2). The composition of the cattle here includes specialists with a higher and secondary special education. These data are obtained from various sources and therefore give only a general idea of the concentration of highly educated personnel in different countries of the 
world in 2016. Nevertheless, their study allows us to draw some fundamentally important conclusions about the intellectual potential of these countries and the effectiveness of its use.

Table 2. Dependence of the economic development of some countries of the world on the level of skill of their workforce

\begin{tabular}{|c|c|c|c|c|c|}
\hline № & country & $\begin{array}{l}\text { Population size } \\
\text { (million people) }\end{array}$ & $\begin{array}{lll}\text { GDP } & \text { (billions } & \text { of } \\
\text { dollars) } & & \end{array}$ & \begin{tabular}{lr} 
Share of the & \multicolumn{1}{c}{ of } \\
world resource \\
of & skilled \\
labor,\% &
\end{tabular} & $\begin{array}{l}\text { Level of qualification } \\
\text { of the workforce, } \%\end{array}$ \\
\hline 1 & USA & 329,1 & 18624,45 & 11,5 & 80,5 \\
\hline 7 & China & 1398 & 11221,8 & 6,7 & 11,0 \\
\hline 3 & Japan & 126,1 & 4949,3 & 5,3 & 96,4 \\
\hline 4 & Russia & 146,5 & 1281,3 & 3,5 & 56,0 \\
\hline 2 & Germany & 81,4 & 3479,2 & 3,1 & 86,5 \\
\hline 5 & Kazakhstan & 18,4 & 134 & 0,4 & 66,0 \\
\hline 6 & Belarus & 9,5 & 48,1 & 0,1 & 26,0 \\
\hline
\end{tabular}

For example, Japan has only slightly more than $5.3 \%$ of the world's cattle resource, compared to $3.5 \%$ in Russia, but at the same time it provides a four times higher level of GDP compared to Russia, what speaks about fundamentally different sources of economic growth in these countries. If we consider Kazakhstan, then by the size of the population, both by the level of qualification of the labor force, and by the size of GDP, there is a significant lag.

Meanwhile, the share of the population with higher and secondary special education in Kazakhstan, although lagging behind the level of technologically developed countries, is $66 \%$, slightly more than in Russia, which indicates the availability of intellectual potential for forming the foundations of a technologically oriented economy. And this resource is important to use effectively for GDP growth, because today, under the influence of globalization, modern IT technologies and the Fourth Industrial Revolution, the approaches to the productivity and nature of human work are changing. Observed over the past decades in economically developed countries, the transition to a knowledge-based high-tech economy is changing the direction towards increasing human sustainability and well-being.

In the structure of a knowledge-based economy as a dominant resource, science was transformed into a direct productive force, the main factor of production. In connection with these, we will analyze the personnel supply of the scientific sector of the Republic of Kazakhstan.

Scientific personnel are specialists of the highest degree of preparation who are directly involved in the process of reproducing scientific knowledge and preparing scientific results for practical use (commercialization). The differentiation of the personnel structure is determined by the specifics of the tasks of the knowledge economy, as well as by the specific nature of scientific and scientific and technical work. It consists of scientists and engineers, management personnel, workers in pilot production, support and maintenance personnel. They are called upon to form "quality" and "prospects" for the further development of the economy and the state. In the opinion of Glazyev (2014), without a quantitative and qualitative staffing of knowledge-intensive sectors - locomotives of economic growth - the transition to both a knowledge-based economy and a new VI technological order is unrealistic.

The staffing of science in the Republic of Kazakhstan not only lags far behind the personnel potential of developed countries, which can be seen from the data in Table 3, but also runs counter to the main world trends, as it decreases year by year. 
Table 3. The main indicators of the human resources potential of developed countries and Kazakhstan in 2016

\begin{tabular}{|r|l|r|r|r|}
\hline № & Country & $\begin{array}{l}\text { Number of scientific } \\
\text { researchers per 1 million } \\
\text { people. }\end{array}$ & Number of researchers & Share of global resource, $\%$ \\
\hline 1 & China & 1177 & 2069650 & $21,2 \%$ \\
\hline 2 & EU 28 & 3485 & 1880000 & $19,3 \%$ \\
\hline 3 & USA & 5709 & 1392751 & $9,3 \%$ \\
\hline 4 & Japan & 231 & 917725 & $9,4 \%$ \\
\hline 5 & India & 4431 & 817426 & $8,4 \%$ \\
\hline 6 & Germany & 7087 & 586030 & $6,0 \%$ \\
\hline 7 & South Korea & 5878 & 460769 & $4,7 \%$ \\
\hline 8 & France & 3131 & 383843 & $3,9 \%$ \\
\hline 9 & Russia & 4599 & 370379 & $3,8 \%$ \\
\hline 10 & Canada & 8300 & 170640 & \\
\hline 11 & Israel & 18 & 70419 & \\
\hline 12 & Kazakhstan & 22000 & \\
\hline
\end{tabular}

It should be noted that the highest proportion of scientists in the world over the past 5 years is observed in Israel. So in 2017, there were 135 employees of the scientific sphere for 10,000 people, whereas in the USA - 85 people. In Kazakhstan, this figure is 12 people. In fact, the country's scientific sector not only has a shortage of scientific personnel, but also experiences its deepening. There are several reasons:

- natural aging of scientific personnel of the country;

- unattractiveness of the scientific sector for scientists;

- outflow of young scientists into business and abroad;

Despite the measures taken by the state to increase the state order for the preparation of PhD masters and doctors, as well as the continuation of the international Bolashak program, the scope of scientific activity continues to be unattractive for most young people due to weak material and social incentives. A significant problem for the country remains the "brain drain" abroad, where there are more attractive material conditions for doing scientific work. Regions of Kazakhstan are experiencing an even greater deficit, as qualified personnel leave for the capital as well. Obviously, a complex of institutional measures will be required, not only stimulating academic activities, but contributing to the attraction of scientific personnel from abroad.

The demand for research and intellectual knowledge in the knowledge economy is constantly increasing. In highly developed countries, this is expressed in the constant increase in the financing of science and the wages of scientists compared with the average for the economy. However, in Kazakhstan, the overall trend of investment in science is somewhat different from the global trend. In general, the dynamics of the share of expenditure on $\mathrm{R} \&$ $\mathrm{D}$ in relation to the GDP of developed countries and Kazakhstan is shown in Figure 1. 


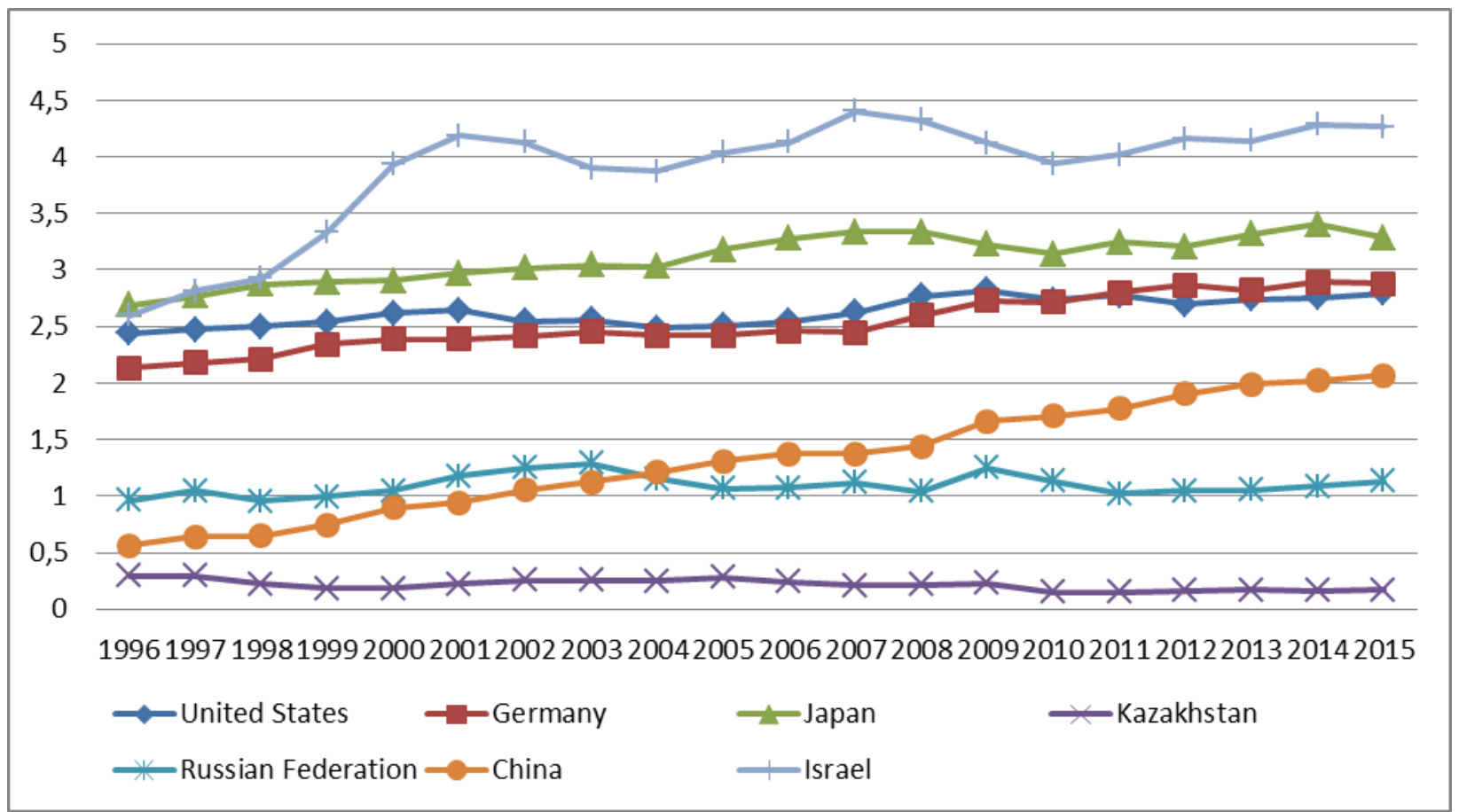

Figure 1. Dynamics of the share of expenditure on R \& D relative to GDP for 1996-2015

In the period from 1996 to 2015, there is a fairly significant increase in the share of spending on R \& D in GDP in China: from $0.5 \%$ to $2.1 \%$. Nevertheless, Israel remains the leader in spending on R \& D. If in absolute terms R \& $\mathrm{D}$ expenditure in Kazakhstan increased by $500 \%$, then the share of R \& D expenditure in GDP in 20 years practically did not change and is less than $0.2 \%$.

Expenditure indicators per capita, according to 2016, also confirm the statistics of a catastrophically low level of funding. This indicator in Kazakhstan is almost ten times less than in the USA, Finland, Sweden, and Japan. It is also interesting to compare the internal costs of research and development per researcher, the values of which are presented in Table 4.

Table 4. Internal costs of research and development per researcher in 2016, thousands of dollars.

\begin{tabular}{|l|r|r|r|}
\hline Country & R\&D Expenditures & Number of researchers & $\begin{array}{l}\text { Expenses for nir for } 1 \text { employee, in } \\
\text { thousands of US dollars }\end{array}$ \\
\hline USA & 540,2 & 1392751 & 387,8 \\
\hline EU 28 & 354,2 & 1880000 & 188,4 \\
\hline Germany & 105,9 & 586030 & 180,7 \\
\hline Japan & 159,8 & 917725 & 174,1 \\
\hline Canada & 28,6 & 170640 & 167,6 \\
\hline France & 57,6 & 383843 & 150,0 \\
\hline South Korea & 64,7 & 460769 & 140,5 \\
\hline Israel & 15,0 & 112428 & 133,2 \\
\hline China & 253,3 & 2069650 & 122,4 \\
\hline
\end{tabular}


The International Journal

ENTREPRENEURSHIP AND SUSTAINABILITY ISSUES

ISSN 2345-0282 (online) http://jssidoi.org/jesi/ 2018 Volume 6 Number 2 (December) http://doi.org/10.9770/jesi.2018.6.2(17)

\begin{tabular}{|l|r|r|r|}
\hline Russia & 17,8 & 370379 & 48,1 \\
\hline India & 16,4 & 817426 & 20,0 \\
\hline Kazakhstan & 0,3 & 22000 & 12,3 \\
\hline
\end{tabular}

As a result, it turns out that Kazakhstan spends 12.3 thousand dollars per person engaged in scientific research and development. From the analysis of the given data, one can see that a huge gap in the level of funding for science, which unambiguously condemns Kazakhstan in the near and medium-term outlook for the overtaking type of development. The transformation of science in the conditions of the knowledge economy into the most important factor of production determines the growth of capital investments in this sector. So, in the US in 2016, science expenditures accounted for more than one-third of total global expenditure $-30 \%$. This is more than in the EU's 28 countries combined - 20\%, in China - 14\% (table 5).

Table 5. Gross domestic product and total spending on science of the world's largest economies in 2016.

\begin{tabular}{|c|c|c|c|c|c|}
\hline \multirow[t]{2}{*}{ Country } & \multicolumn{2}{|l|}{ GDP } & \multirow{2}{*}{$\begin{array}{c}\text { Expenditure on R \& } \\
\text { D in GDP, } \%\end{array}$} & \multicolumn{2}{|c|}{ Total expenditure on science } \\
\hline & billion dollars. & $\begin{array}{l}\text { in } \% \text { of the world } \\
\text { value }\end{array}$ & & billion dollars. & $\begin{array}{l}\text { in } \% \text { of the world } \\
\text { value }\end{array}$ \\
\hline USA & 19361 & $24,0 \%$ & 2,79 & 540,2 & $30 \%$ \\
\hline Japan & 4872,1 & $6,0 \%$ & 3,28 & 159,8 & $9 \%$ \\
\hline Germany & 3677,4 & $4,6 \%$ & 2,88 & 105,9 & $6 \%$ \\
\hline South Korea & 1530,7 & $1,9 \%$ & 4,23 & 64,7 & $4 \%$ \\
\hline Israel & 350,8 & $0,4 \%$ & 4,27 & 14,9 & $1 \%$ \\
\hline France & 2582,5 & $3,2 \%$ & 2,23 & 57,6 & $3 \%$ \\
\hline Canada & 1653,0 & $2,0 \%$ & 1,73 & 28,6 & $2 \%$ \\
\hline Russia & 1577,5 & $2,0 \%$ & 1,13 & 17,8 & $1 \%$ \\
\hline EU 28 & 17278 & $21,4 \%$ & 2,05 & 354,2 & $20 \%$ \\
\hline China & 12238,0 & $15,2 \%$ & 2,07 & 253,3 & $14 \%$ \\
\hline India & 2597,4 & $3,2 \%$ & 0,63 & 16,4 & $1 \%$ \\
\hline Kazakhstan & 159,4 & $0,2 \%$ & 0,17 & 0,3 & $0 \%$ \\
\hline $\begin{array}{l}\text { Total in the } \\
\text { world }\end{array}$ & 80684,0 & & 2,23 & 1796,8 & \\
\hline
\end{tabular}

We note that the development paradigm of Industry 4.0, based on its economic nature based on high technologies, determines new requirements for the resource base, which is ensured by the quality and efficiency of the use of intellectual capital. This fact objectively limits further economic growth of Kazakhstan at the expense of extraction and export of natural resources and actualizes the necessity of financing science on a leading principle. As a specific result of intellectual work is information about the results of previous research, development and development of innovations. Its carriers are thematic maps of the research begun, reports on completed research and development, publications and dissertations containing new theories, hypotheses, recommendations, descriptions, formulas, schemes, drawings, etc.

The state of the information component of the scientific potential can be judged in particular by the dynamics of publications of Russian scientists in the world's leading journals and databases, and by the number of references to their works. Data on published articles in G7, BRIC and Kazakhstan are given in Table 6. 
Table 6. Distribution of the flow of articles in G7, BRIC and Kazakhstan in 2016,\%

\begin{tabular}{|l|l|l|}
\hline Country & Number of articles & Share in $\%$ \\
\hline USA & 715297 & $31,9 \%$ \\
\hline China & 440070 & $19,6 \%$ \\
\hline United Kingdom & 183657 & $8,2 \%$ \\
\hline Germany & 170126 & $7,6 \%$ \\
\hline Japan & 126208 & $5,6 \%$ \\
\hline India & 126154 & $5,6 \%$ \\
\hline France & 116418 & $5,2 \%$ \\
\hline Italy & 113135 & $5,0 \%$ \\
\hline Canada & 110044 & $4,9 \%$ \\
\hline Brazil & 70692 & $3,2 \%$ \\
\hline Russia & 68906 & $3,1 \%$ \\
\hline Kazakhstan & 2511 & $0,1 \%$ \\
\hline
\end{tabular}

It should be noted that in the period from 2012 to 2016 the number of publications of articles of domestic scientists has tripled. In 2012, 754 articles, abstracts and other conference materials were published, and in 2016 2241. It is noteworthy that the increase in the publication activity of Kazakhstani scientists was the result of the requirements for writing doctoral dissertations and for the implementation of research projects implemented at the expense of state funding. At the same time, a number of humanitarian publications tended to fall into fake scientific journals. Thus, there was a need for additional institutional measures to stimulate the increase in the effectiveness of scientific workers and limiting low-quality publications.

Despite the fact that the volume of knowledge and information has increased exponentially in recent years, an extremely modest role is played in the developed information space in the Republic of Kazakhstan. She owns only about $0.1 \%$ of the global distribution of the flow of articles. It is significant that the United States owns about $1 / 3$, or $31.9 \%$ of all indexed materials, which determines the status of the country-leader in the modern information society.

The reasons for the poor publication activity and citation of Kazakh scientists are related to the relatively low quality of scientific research, as well as ignorance of the English language. So, according to some information, only $10 \%$ of native scientists speak English and can study documents in the original on English-language sites. This circumstance forces domestic scientists to post their materials only in national editions. As a result, published articles are largely unclaimed. All this makes Kazakhstan only a recipient of scientific products and contributes to the inevitable degradation of the information potential of the country.

Patents for inventions reflect the effectiveness, scientific novelty of ongoing research and development. Patents act as objects of sale and purchase in the knowledge market, generate rental incomes for both individual organizations and the country as a whole. As statistical studies show, despite the rather high dynamics of the publication and patent activity of scientists of the country over the past three years, in general, it continues to noticeably lag behind the results of the leading countries. According to various sources, the revenues of the budgets from the sale of science-intensive products make up \$700 billion in the US, \$530 billion in Germany, and \$ 400 billion in Japan. The receipt of applications and the issuance of patents in the RK is $0.07 \%$ of the 
The International Journal

ENTREPRENEURSHIP AND SUSTAINABILITY ISSUES

ISSN 2345-0282 (online) http://jssidoi.org/jesi/

2018 Volume 6 Number 2 (December)

http://doi.org/10.9770/jesi.2018.6.2(17)

production of high technology products in the world.The dynamics of the number of issued patents in the country profile is given in Table 7.

Table 7. Number of patents received in the country by 20161

\begin{tabular}{|l|l|r|r|}
\hline № & Country & Number of patents & $\begin{array}{l}\text { Share of total patents in the } \\
\text { world, } \%\end{array}$ \\
\hline 1 & China & 1257439 & $59,05 \%$ \\
\hline 2 & USA & 521802 & $24,50 \%$ \\
\hline 3 & Japan & 456467 & $21,43 \%$ \\
\hline 4 & South Korea & 233786 & $10,98 \%$ \\
\hline 5 & Germany & 177073 & $8,32 \%$ \\
\hline 6 & France & 71486 & $3,36 \%$ \\
\hline 7 & United Kingdom & 52909 & $2,48 \%$ \\
\hline 8 & Switzerland & 47000 & $2,21 \%$ \\
\hline 9 & Netherlands & 39058 & $1,83 \%$ \\
\hline 10 & Russia & 31815 & $1,49 \%$ \\
\hline 11 & Canada & 24653 & $1,16 \%$ \\
\hline 12 & Sweden & 23453 & $1,10 \%$ \\
\hline 13 & Spain & 10807 & $0,51 \%$ \\
\hline 14 & Kazakhstan & 1527 & $0,07 \%$ \\
\hline 15 & Finland & 1256 & $0,06 \%$ \\
\hline & Total in the world & 2129552 & \\
\hline
\end{tabular}

The increment in the number of issued patents for inventions in Kazakhstan is ten times lower than the similar figures for the number of patents issued in other countries. Low patent activity of domestic scientists and inventors in comparison with their foreign colleagues characterizes the emerging level of innovative and intellectual development of Kazakhstan and fairly objectively reflects the place that our country occupies in the global intellectual products market. In Kazakhstan, thus, they prefer to engage in servicing activities, rather than creative and creative, as researchers around the world. This, of course, is due primarily to the level of pay for intellectual workers, which is incommensurably low, than abroad, and also with low prestige in the society of the profession of the scientist.

According to some experts, it is with the change of technological structures that there is a rare opportunity to enter a new way with minimal costs in lagging countries, which inspires some optimism about Kazakhstan, which actively promotes the development of a knowledge-based economy.

Thus, summarizing the comparative analysis of the development of a knowledge-based economy in Kazakhstan, it can be concluded that in spite of innovative state initiatives and systematic government policy to increase the training of scientific personnel, there continues to be a shortage of intellectual resources, a low level of generating new ideas and the volumes of science financing remain minimal.

For an adequate response to the challenges of Industry 4.0, Kazakhstan will not only increase intellectual resources, but also take care of their quality. At this stage, scientists are needed that can not only work in the context of the sixth technological order, but also generate new ideas for new industries, obtaining patents, commercializing innovations. 
At this stage, with relatively low levels of science intensity of industries operating in the country, as well as insignificant volumes of innovative products, it is important to clarify: "What is the real contribution of intellectual resources that exist in the country to the growth of innovative production of the national economy?"

\section{Research Methodology}

Specificity of the national economy, caused by the above factors, determines the need to develop special criteria to measure the intellectual capital of the regions, which should be consolidated and effectively used to solve the priority tasks of the new technological order. Since at this stage we can only talk about the formation of a knowledge-based economy in the regions of the country, the methodology for measuring intellectual security of the high-tech development of Kazakhstan should, in our opinion, take into account both the negative and positive "contribution" of this or that factor to the innovative component of the gross national product . In this regard, we proposed a multifactor model that makes it possible to use both quantitative and qualitative parameters of intellectual provision of the knowledge-based economy of regions and the country as a whole, assessing the availability, intensity and effectiveness of the use of intellectual resources.

Our methodology for assessing intellectual property at the regional and national levels includes the following quantitative indicators:

1. The availability of intellectual potential for a knowledge-based economy:

- percentage of population with higher education;

- the share of workers in the scientific sector in the total population;

- The share of PPP in the total population;

- the share of employees employed in high-tech industries;

- share of wages of scientific workers in the total wage fund;

- share of salaries of PPP workers in the total wage fund;

- share of small (innovative) enterprises in the total number of enterprises;

- share of enterprises using the Internet to the total number of enterprises.

To assess the quality of intellectual security, we suggest using indicators that enable us to assess the extent and results of using intellectual capital in the regions:

2. Intensity of the use of intellectual capital:

- The share of patents and articles received with the impact factor in the total share of scientific research;

- share of enterprises using foreign technologies in the total number of enterprises;

- share of enterprises using new technologies in the total number of enterprises;

- share of R \& D costs in the gross regional product.

3. Results of the use of intellectual capital:

- The share of patents per worker in the scientific sector;

- share of commercialized patents in the total number of patents received;

- The share of innovative products in the gross regional product.

The hypothesis of our research is that there are indicators that have the greatest impact on the volume of innovative products. Since the end product of knowledge-based production is an innovative product with the maximum added value through the use of new knowledge, a hypothesis has been proposed that the volume of innovative products in the Republic of Kazakhstan is affected by a number of variables that are indicators of the availability and intensity of the use of intellectual capital. Further analysis will show whether it is possible to predict the values of the dependent variable depending on the value of one or more independent variables.

Define the main indicators of our future model in Table 8. 
Table 8. Intellectual Property Assessment Scenarios

\begin{tabular}{|l|l|}
\hline Index & Decoding of the indicator \\
\hline X1 & Proportion of population with higher education; \\
\hline X2 & The share of workers in the scientific sector in the total population; \\
\hline X4 & The share of PPP in the total population; \\
\hline X5 & Share of workers employed in high-tech industries; \\
\hline X6 & The share of wages of scientific workers in the total wage fund; \\
\hline X7 & Share of salaries of PPP workers in the total wage fund; \\
\hline X8 & The share of small (innovative) enterprises in the total number of enterprises; \\
\hline X9 & Share of enterprises using the Internet to the total number of enterprises; \\
\hline X10 & The share of patents and articles received with the impact factor in the total share of scientific research; \\
\hline X11 & The share of R \& D costs in the gross regional product \\
\hline X12 & Share of enterprises using new technologies in the total number of enterprises; \\
\hline X13 & Share of enterprises using foreign technology in the total number of enterprises; \\
\hline X14 & The share of patents per worker in the scientific sector; \\
\hline Y & Share of commercialized patents in the total number of patents received; \\
\hline
\end{tabular}

Next, using regression analysis, we construct a model. The main feature of regression analysis: with its help, you can get specific information about the form and nature of the relationship between the variables studied.

\section{Model building and analysis of results}

To assess the reliability of the proposed indicators, a study was made of the statistical relationships between the proposed indicators using the SPSS program. The analysis of the influence of a number of variables on the volume of innovative products in the Republic of Kazakhstan is carried out. A total of 14 annual observations were used. The initial data is given in Appendix 1.

We will perform a regression analysis of independent variables to determine the indicators that have the greatest impact on the share of innovative products in GNP. We construct the first correlation model with 14 independent variables using the specialized program for econometric analysis of SPSS. The analysis showed the following results (Table 9). 
Table 9. Regression analysis using the SPSS econometric analysis program

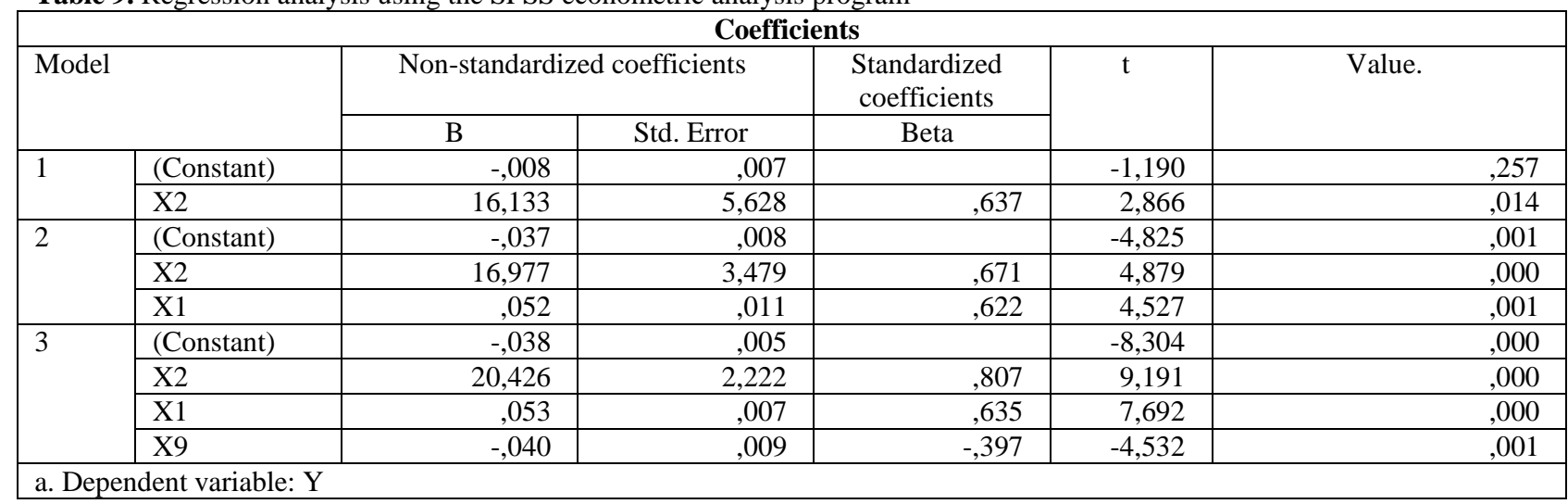

The program in three steps selected indicators that affect the share of innovative products in GDP. The indicators are reflected by the degree of dependence:

1. The share of workers in the scientific sector in the total population.

2. Proportion of population with higher education.

3. The share of patents and articles received with the impact factor in the total share of scientific research.

Let's check this model with Excel. For this, it is necessary to perform a correlation analysis and to find the relationship between the quantities. The obtained correlation coefficients showed the dependence of the variable $\mathrm{Y}$ on the indices $\mathrm{X} 1, \mathrm{X} 2, \mathrm{X} 9$ (Table 10).

Table 10. Interrelation of the variables $Y$ with the indices $X 1, X 2, X 9$

\begin{tabular}{|c|c|c|c|c|}
\hline $\mathrm{t}$ & $\mathrm{Y}$ & $\mathrm{X} 1$ & $\mathrm{X} 2$ & $\mathrm{X} 9$ \\
\hline 2004 & 0,0127 & 0,5560 & 0,0011 & 0,0389 \\
\hline 2005 & 0,0159 & 0,5716 & 0,0013 & 0,0345 \\
\hline 2006 & 0,0153 & 0,5575 & 0,0013 & 0,0351 \\
\hline 2007 & 0,0119 & 0,5250 & 0,0012 & 0,0531 \\
\hline 2008 & 0,0069 & 0,4933 & 0,0010 & 0,0729 \\
\hline 2009 & 0,0049 & 0,4960 & 0,0010 & 0,0881 \\
\hline 2010 & 0,0065 & 0,4950 & 0,0011 & 0,0858 \\
\hline 2011 & 0,0084 & 0,5314 & 0,0011 & 0,0888 \\
\hline 2012 & 0,0122 & 0,5339 & 0,0012 & 0,0985 \\
\hline 2013 & 0,0161 & 0,5090 & 0,0014 & 0,0974 \\
\hline 2014 & 0,0146 & 0,4837 & 0,0015 & 0,1060 \\
\hline 2015 & 0,0092 & 0,4844 & 0,0014 & 0,1367 \\
\hline 2016 & 0,0095 & 0,5114 & 0,0013 & 0,1425 \\
\hline 2017 & 0,0163 & 0,6600 & 0,0012 & 0,1549 \\
\hline
\end{tabular}

Next, we perform a regression analysis that will allow us to estimate the degree of coupling between the variables by calculating the expected value of the variable based on several known values.

First, consider the upper part of the calculations presented in Table 11 - regression statistics. 
Table 11. Regression statistics

\begin{tabular}{|l|l|}
\hline Regression statistics & 0,965459 \\
\hline Multiple R & 0,932111 \\
\hline R-square & 0,911744 \\
\hline The normalized R-square & 0,001158 \\
\hline Standard Error & 14 \\
\hline Observations & \\
\hline
\end{tabular}

The value of the R-square, also called a measure of certainty, characterizes the quality of the regression line obtained. In our model, the measure of certainty is 0.932111 , which indicates a very good fit of the regression line to the original data.

The multiple $\mathrm{R}$ is equal to the Pearson correlation coefficient (0.965459). Multiple $\mathrm{R}$ - coefficient of multiple correlation $\mathrm{R}$ - expresses the degree of dependence of independent variables $(\mathrm{X})$ and the dependent variable $(\mathrm{Y})$ (Table 12).

Table 12. Coefficients of regression

\begin{tabular}{|l|l|l|l|l|l|l|l|l|}
\hline & Coefficients & $\begin{array}{l}\text { Standard } \\
\text { error }\end{array}$ & -statistics & P-Value & $\begin{array}{l}\text { Lower } \\
95 \%\end{array}$ & $\begin{array}{l}\text { The top } \\
95 \%\end{array}$ & $\begin{array}{l}\text { Lower } \\
95.0 \%\end{array}$ & $\begin{array}{l}\text { The } \\
95.0 \%\end{array}$ \\
\hline $\begin{array}{l}\text { Y- } \\
\text { intersection }\end{array}$ & $-0,03778$ & 0,00455 & $-8,3036$ & $8,48 \mathrm{E}-06$ & $-0,04792$ & $-0,02764$ & $-0,04792$ & $-0,02764$ \\
\hline $\begin{array}{l}\text { Variable X } \\
1\end{array}$ & 0,052554 & 0,006832 & 7,692224 & $1,66 \mathrm{E}-05$ & 0,037331 & 0,067777 & 0,037331 & 0,067777 \\
\hline $\begin{array}{l}\text { Variable X } \\
2\end{array}$ & 20,42558 & 2,222445 & 9,190592 & $3,43 \mathrm{E}-06$ & 15,47367 & 25,3775 & 15,47367 & 25,3775 \\
\hline $\begin{array}{l}\text { Variable X } \\
3\end{array}$ & $-0,03964$ & 0,008746 & $-4,5323$ & 0,001088 & $-0,05912$ & $-0,02015$ & $-0,05912$ & $-0,02015$ \\
\hline
\end{tabular}

Thus, our correlation model, calculated using Excel, as well as in SPSS, looks like this:

$\mathrm{Y}=-0.038+20.426 *$ Proportion of employees in the scientific sector in the total population $+0.053 *$ Proportion of population with higher education $-0.040 *$ Proportion of patents and articles with impact factor in the total share of scientific research.

Due to the fact that the variable X3 is negative for the regression coefficient, the relationship of the given dependent variable with the independent variable is negative (inverse). The relationship with the remaining variables is positive.

Table 13 shows the results of the derivation of the residues.

Table 13. Residuals

\begin{tabular}{|l|l|l|}
\hline Observation & Predicted $Y$ & Remains \\
\hline 1 & 0,012731 & $-2,5 \mathrm{E}-06$ \\
\hline 2 & 0,016515 & $-0,00065$ \\
\hline 3 & 0,016381 & $-0,0011$ \\
\hline 4 & 0,011286 & 0,000582 \\
\hline 5 & 0,006642 & 0,000306 \\
\hline 6 & 0,004977 & $-0,00012$ \\
\hline 7 & 0,00629 & 0,000226 \\
\hline
\end{tabular}




\begin{tabular}{|l|l|l|}
\hline 8 & 0,008995 & $-0,00064$ \\
\hline 9 & 0,01137 & 0,00085 \\
\hline 10 & 0,013751 & 0,002313 \\
\hline 11 & 0,014138 & 0,00049 \\
\hline 12 & 0,011267 & $-0,00204$ \\
\hline 13 & 0,010017 & $-0,00053$ \\
\hline 14 & 0,015936 & 0,000319 \\
\hline
\end{tabular}

With this part of the report, we can see the deviations of each point from the constructed regression line. The greatest absolute value of the remainder in our case is 0.016515 , the smallest is 0.004977 . For a better interpretation of these data, we use the graph of the original data and the constructed regression line, shown in Figure 2. As you can see, the regression line is accurately "matched" to the values of the original data.

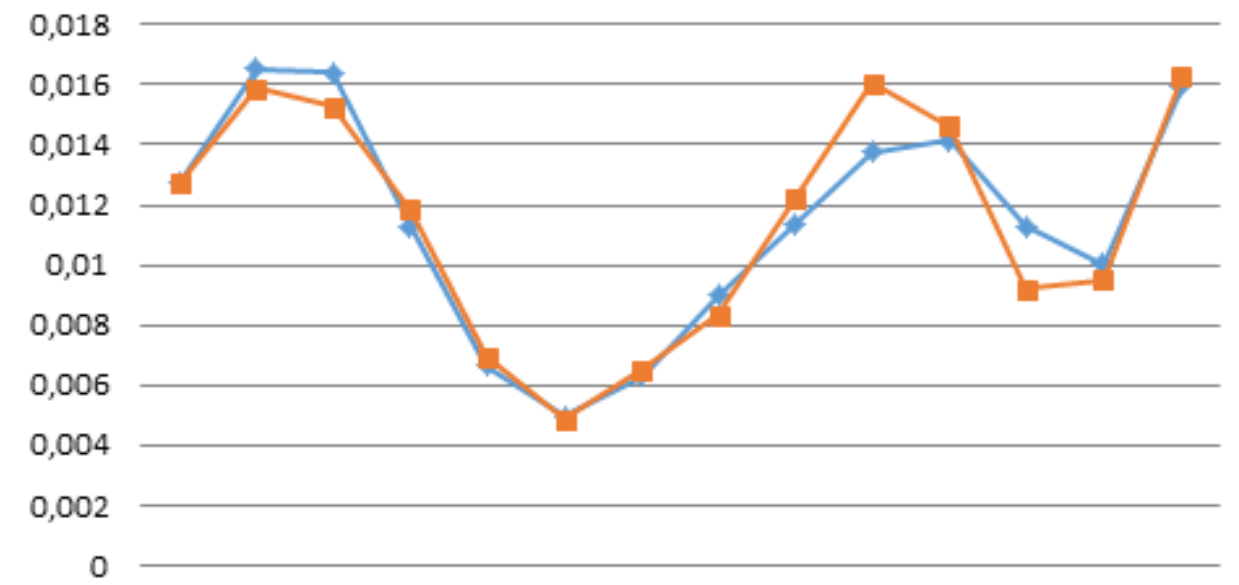

20042005200620072008200920102011201220132014201520162017

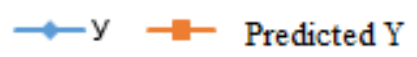

Figure 2. Initial data and regression line

Consider an estimate of the unknown future values of the dependent variable based on known values of the independent variable, that is, we solve the prediction problem.

Having the regression equation, the prediction problem reduces to solving an equation with known values of $\mathrm{x}$. The results of forecasting the dependent variable Y six steps forward are presented in Table 14. The analysis showed that the forecast figure should increase by $6.3 \%$.

Table 14. Results of predicting the variable $\mathrm{Y}$

\begin{tabular}{|r|r|r|l|}
\hline \multicolumn{1}{|c|}{ Observation } & Predicted $Y$ & $e$ & $\%$ \\
\hline 1 & 0,012731 & $-2,5 \mathrm{E}-06$ & $0,02 \%$ \\
\hline 2 & 0,016515 & $-0,00065$ & $4,11 \%$ \\
\hline 3 & 0,016381 & $-0,0011$ & $7,22 \%$ \\
\hline 4 & 0,011286 & 0,000582 & $4,90 \%$ \\
\hline 5 & 0,006642 & 0,000306 & $4,40 \%$ \\
\hline
\end{tabular}




\begin{tabular}{|r|r|r|l|}
\hline 6 & 0,004977 & $-0,00012$ & $2,48 \%$ \\
\hline 7 & 0,00629 & 0,000226 & $3,47 \%$ \\
\hline 8 & 0,008995 & $-0,00064$ & $7,66 \%$ \\
\hline 9 & 0,01137 & 0,00085 & $6,96 \%$ \\
\hline 10 & 0,013751 & 0,002313 & $14,40 \%$ \\
\hline 11 & 0,014138 & 0,00049 & $3,35 \%$ \\
\hline 12 & 0,011267 & $-0,00204$ & $22,12 \%$ \\
\hline 13 & 0,010017 & $-0,00053$ & $5,55 \%$ \\
\hline 14 & 0,015936 & 0,000319 & $1,96 \%$ \\
\hline \multicolumn{2}{|r|}{} & & $6,3 \%$ \\
\hline
\end{tabular}

Republic of Karelia on real statistical data, a correlation-regression analysis was carried out, which can predict the volume of innovative products. During the work on regression analysis, it was possible to construct a multiple regression model, with the help of which it is possible to correctly explain the behavior of the dependent variable with an accuracy of $99 \%$.

\section{Conclusions}

Thus, the analysis of the innovative development of the Kazakh economy in comparison with the world's leading economies, answering the first question "What and in what quantity are intellectual resources needed for the creation and functioning of a knowledge-based economy in Kazakhstan that is striving to move away from the catch-up development model?", : "Intellectual potential has small quantitative values for virtually all regions of the country, and its use in the form of intellectual capital is neeffe in the context of the development of a knowledge-based economy. "

\section{Causes:}

- low quality of higher education, which, with a broad population coverage, does not realize the mission of development of the research component in the industry development trend 4.0

- a small number of people engaged in the scientific sector and the low quality of personnel selection in this field;

- insufficient level of dissemination of modern knowledge-intensive and information technologies;

- low level of financing of research activities;

- low rates of generation and commercialization of new knowledge;

- Ineffective public funding for ongoing research;

- Inconsistent implementation of innovative projects;

- low innovative activity of enterprises and the share of innovative products in the gross regional product.

Answering the second question of the study: "What methods of measuring intellectual potential and intellectual capital can be used for the national economy of Kazakhstan in the context of the transition to a knowledge-based economy?", It should be concluded that the proposed calculations allow determining that the increase in the innovative component of the gross national product in Kazakhstan The greatest influence is exerted by the share of scientific personnel in the total population, the proportion of people with higher education in the total population, and the number of patents and articles with impact factor in the total number of scientific studies. The obtained results allow drawing a conclusion about the need to increase the share of workers in the scientific sector, the number of people with higher education and to improve the quality of ongoing scientific research. 
The International Journal

ENTREPRENEURSHIP AND SUSTAINABILITY ISSUES

ISSN 2345-0282 (online) http://jssidoi.org/jesi/

2018 Volume 6 Number 2 (December)

http://doi.org/10.9770/jesi.2018.6.2(17)

\section{References}

Balatsky, O.F. (2004). Theoretical problems of assessing the economic potential of the region, companies, enterprises // News of SumU, No. 9 (68). Pp. 84-95. [Balatsky OF (2004). Theoretical problems of assessing the economic potential of the region, the company, the enterprise. Visnik SumDU, No. 9 (68), pp. 84-95. (In Russian).]

Glazyev, S.Yu. (2014). Strategic preconditions for modernization and innovative development of the Russian economy. Moscow: GUU, 274 pp. [Glazyev S.Yu. (2014). Strategic preconditions for modernization and innovation development of the Russian economy. Moscow: GUU, 274 p. (In Russian).]

Ілляшенка, C.M. (2004). Management is marketing and innovation. Sumi: ВТД Університет книга, 616 c. [Illyashenko S.M. (2004). Management and marketing of innovations. Sumy: VTD University Book, 616 p. (In Russian).]

Bec, Brigita (2014). Moč intelektualnega kapitala. http://www.poslovnisvet.si/vodenje/moc-intelektualnega-kapitala/ 20.8 . 2015.

Bontis, N. (2004). National Intellectual Capital Index: A United Nations Initiative for the Arab Region, Journal of Intellectual Capital, Vol. 5 Issue: 1, pp.13-39, https://doi.org/10.1108/14691930410512905

Druncker, P. (1992). The New Society of Organizations, Harvard Business Review, September-October.

European Commission. (2013). Comparing the innovation performance of the EU Member States, MEMO / 13/274

International Federation of Accountants (IFAC). (1998). The Measurement and Management of Intellectual Capital: An Introduction. Study 7, IFAC, New York.

Lev, B., \& Daum, J.H. (2004). The Dominance of Intangible Assets: Consequences for Enterprise Management and Corporate Reporting. Measuring Business Excellence, 8 (1), 1-6. http://dx.doi.org/10.1108/13683040 410524694

Lin Yeh-Yun, Carol and Leif Edvinsson. (2010). National intellectual capital: comparison of the Nordic countries. New York: SpringerVerlag.

Organization for Economic Co-operation and Development (OECD). (1999). Guidelines for OECD Symposium, International Symposium Measuring Reporting, Intellectual Capital: Experiences, Issues, and Prospects, June, Amsterdam, OECD, Paris.

Romilio Labra, M., \& Paloma Sánchez. (2013). National intellectual capital assessment models: a literature review, Journal of Intellectual Capital, 14 (4), 582-607. https://doi.org/10.1108/JIC-11-2012-0100

Skyrme, J. David (2007): Measuring Knowledge: A Plethora of Methods. David Skyrme Associates. Dostopno prek: http://www.skyrme.com/insights/24kmeas.htm 6. 3. 2015.

United Nations Development Program (UNDP). (1998). HUMAN DEVELOPMENT REPORT 1998 New York Oxford Oxford University Press

World Bank. (1999). World development indicators 1999 (English). World Development Indicators. Washington, DC: The World Bank. http://documents.worldbank.org/curated/en/705141468741325522/World-development-indicators-1999 
The International Journal

ENTREPRENEURSHIP AND SUSTAINABILITY ISSUES

ISSN 2345-0282 (online) http://jssidoi.org/jesi/

2018 Volume 6 Number 2 (December)

http://doi.org/10.9770/jesi.2018.6.2(17)

Rimma Sagiyeva is the Professor of Economics at al-Farabi Kazakh National University. She is a dean of High school of Business and Economics. She was awarded as a best teacher in 2017 Research interests: entrepreneurship and regional development; innovation and small firms; small firm internationalization; sustainability.

ORCID ID: https://orcid.org/0000-0002-7447-268X

Aziza Zhuparova is $\mathrm{PhD}$ in Economics at al-Farabi Kazakh National University. She is a Senior Researcher at the Center of Economic Research. Research interests: innovation development; financing innovation processes; small firm internationalization; sustainability.

ORCID ID: https://orcid.org/0000-0002-5787-760X

Rashid Ruzanov is PhD in Economics at the institute of economy of Committee of science of the Ministry of Education and Science of the Republic of Kazakhstan. Research interests: entrepreneurship and regional development; human capital; small firm internationalization; sustainability.

ORCID ID: https://orcid.org/0000-0003-4913-3886

Raigul Doszhan is PhD in Economics at al-Farabi Kazakh National University. He is a Senior Researcher at the Center of Economic Research. Research interests: innovation development; financing innovation processes; small firm internationalization; sustainability.

ORCID ID: https://orcid.org/0000-0001-6440-917X

Askar Askerov is Doctorate Student at High school of Business and Economics of al-Farabi Kazakh National University. Research interests: entrepreneurship and regional development; innovation and small firms; small firm internationalization; sustainability.

ORCID ID: https://orcid.org/0000-0002-7898-1908

Copyright (C) 2018 by author(s) and VsI Entrepreneurship and Sustainability Center

This work is licensed under the Creative Commons Attribution International License (CC BY).

http://creativecommons.org/licenses/by/4.0/

c) (†) Open Access 